\title{
The Technical Analysis of On-Grid Photovoltaic Power Plant Implementation: Case Study of Elbasan, Albania
}

\author{
Virtyt Lesha \\ Polytechnic University of Tirana
}

\section{Abstract}

The motive of importance that has been given to renewable energy throughout the world, especially over the last five years, comes from a number of reasons. These reasons roughly point to the very rapid advancement of technology in all areas of life. The growing needs for energy sources are in function among other cases mentioned above or in the fast demographic growth of the world. In this paper, we discuss a practical case study on implementing an on-grid photovoltaic plant. The case study is considered in technical terms, and gives some discussion on the beneficial effects of using solar energy for the production of electric energy. A photovoltaic plant was implemented in the city of Elbasan. Albania based on preliminary simulations in terms of data such as geographical coordinates, solar radiation on the site in question and the nature of site's relief where the plant was implemented. The results and discussion of the study in question consist in the technical quantitative presentation of the energy benefits provided by the photovoltaic plant and the economic impact in consumer and state level.

Keywords: photo-voltaic, technology, simulations, renewable, on-grid JEL classification: O33, Q42

\section{Introduction}

The increase of energy demand in order to exploit and achieve the objectives of the different fields of study or development projects has led to the stimulation of the development of different energy sources. This is because non-renewable energy is in its mining both quantitative and in terms of increasingly renewable energy trends as an alternative to use for different projects and purposes (Provey et al., 2011). According to official studies and definitions, renewable energy is defined, as "renewable energy is an energy resource that is quickly replaced by a natural process such as power generated from the sun or from the wind".

Developed countries are targeting all the humans to renewable energy, especially to exploiting solar power to produce electricity as a variant that is constantly updated and can be recuperated economically (Dunlop, 2012). As far as the latter is concerned, economic recovery consists of the first investment of the photovoltaic plant implementation. Therefore, the solar panel that uses solar energy to produce energy, and then the produced energy can be used for own effects and the remaining part is sold the relevant entity for further use (Isabella et al., 2016).

Currently, the European Union is defining policies that promote the promotion of the development of renewable resources and for consequence Albania as a country with the status of a candidate country (Prowse, 2017). The objective of EU membership in February 2017 has adopted laws and norms regulating the implementation of plants in words; these directives are consistent with the E.U 
regulations and describe in detail the technical and economic procedures to be followed to implement a photovoltaic system. These rules are special for customer profiling as opposed to investor profiling (Lebrac, 2017). The customer profile, consisting in the implementation of a photovoltaic system, is considered as such in the context that the plant will be used for personal needs, thereby avoiding dependence on OSHEE (Operator of Distributing the Electrical Energy). The investor profile consists of such activities that implement the plant only for trading and sales of OSHEE in order to process the investment of the photovoltaic plant (Perlin, 2013).

The issue addressed in this paper elaborated and analysed from the technical aspect the project of implementation of a photovoltaic plant in Elbasan, Albania. This project is a well-known technical component of a photovoltaic system, and provides an opportunity to ascertain the benefits economic/ecological environment that has led to the implementation of such plants in mass (Chiras, 2011).

Moreover, the purpose of this paper was the analysis of the comparison from the technical spectacle to the technical standards set by the European Union. Moreover, the risk analysis and the benefits in the economic spectrum are indicated in the context of the implementation of such plants.

Recently, this paper addressed the case study implemented in the city of Elbasan, Albania and the treatment was a technical profile specifying all relevant technical parameters of the plant in question. The purpose was to present the advantages of the use of photovoltaic plants by the technology used depending on the model of the photovoltaic cell used in the case of the study. The other equipment that are part of the implementation of this plant include inverters, the transformer model.

\section{The analysis methodology in function of the results}

The project in mention relates to the construction of plant producing electricity through photovoltaic conversion, with a peak power equal to 97, $47 \mathrm{kWp}$.

Table 1

The geographical data of the plant

\begin{tabular}{ll}
\hline Location: & Elbasan \\
Latitude: & $041^{\circ} 13^{\prime} 12^{\prime \prime}$ \\
\hline Longitude: & $020^{\circ} 10^{\prime} 44^{\prime \prime}$ \\
\hline Altitude: & $1101 \mathrm{~m}$ \\
\hline Source: Sioner Srlproject &
\end{tabular}

Source: Sioner S.r.l project

The amount of producible electricity will be calculated on the basis of radiometric data indicated in the standard Electro-Graphics.

For plants the following conditions will be met (to be done for each "photovoltaic generator", understood as a set of photovoltaic modules with the same slope and same orientation): at the start-up of the photovoltaic system, the relationship between the energy or power produced into alternating current and the energy or power producible in alternating current (determined as a function of solar radiation incident on the surface of the modules, rated system and the operating temperature of the modules) must be at least greater than 0.78 when using inverter power up to $20 \mathrm{~kW}$ and 0.8 in the case of using higher power inverters, under the conditions of measurement and calculation methods described in EN 60904-2.

It will not be admitted to the parallel strings that are not perfectly identical to each other for exposition, and/or brand, and/or model, and/or number of modules used. Each module, then, will be equipped with bypass diode. 
The photovoltaic system consists of No. 1 photovoltaic generators composed of No. 342 photovoltaic modules and No. 1 inverters with type of realization Type 1 $[€ / \mathrm{kWh}]$.

The total rated power is $97,47 \mathrm{kWp}$ for an annual production of $136.428,1 \mathrm{kWh}$ distributed over an area of $571,14 \mathrm{~m}^{2}$.

The plant reduces emissions into the atmosphere annually as reported in the following table.

Table 2

The Emission Level of the Gases

\begin{tabular}{|c|c|}
\hline Sulphur dioxide (SO2): & $95,61 \mathrm{~kg}$ \\
\hline Oxides of nitrogen (NOx): & $120,37 \mathrm{~kg}$ \\
\hline Powders: & $4,27 \mathrm{~kg}$ \\
\hline Carbon dioxide (CO2): & $71,15+$ \\
\hline $\begin{array}{l}\text { Hydrogen sulfide (H2S) } \\
\text { (geothermal fluid): }\end{array}$ & $4,18 \mathrm{~kg}$ \\
\hline Carbon dioxide (CO2): & $0,81 \dagger$ \\
\hline Tons of oil equivalent (TEP): & $34,11 \mathrm{TEP}$ \\
\hline
\end{tabular}

The generator consists of No. 342 type modules Polycrystalline silicon with an estimated useful life of more than 20 years and degradation of production due to aging of $0,4 \% \%$ per annum

Figure 1

The Simulation Scheme of Physical Configuration of the Photovoltaic Plant

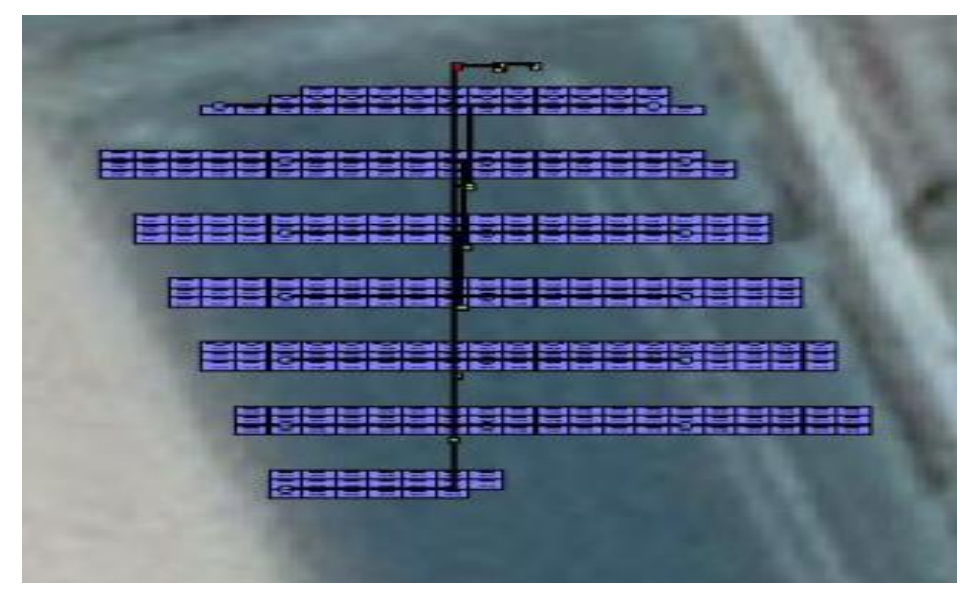

Source: Google Earth

Table 3

The Parameters of the Inverter

\begin{tabular}{ll}
\hline Inverter 1 & MPPT 1 \\
\hline Modules in series: & 18 \\
\hline Parallel strings: & 19 \\
\hline Exposures: & SUD \\
MPP voltage (STC): & $575,82 \mathrm{~V}$ \\
\hline
\end{tabular}

Source: Sioner S.r.l project 
The voltage values at various operating temperatures (minimum, maximum and operating) fall within the acceptable range allowed by the inverter.

The electrical line that arrives from photovoltaic modules is grounding by appropriate Surge Protection Devices with "out of service" optical indicator, to guar.

The conversion system consists of static converters (inverters).

The converter DC/AC used is fit for the transfer of power from the PV array to the network of the distributor, in accordance with the technical regulatory requirements and safety standards. The values of input voltage and input current of this device are compatible with those of the respective photovoltaic field, while the values of output voltage and output frequency are compatible with those of the network that is connected to the system.

The main features of the conversion system are:

- Forced switching inverter with PWM technique (pulse-width modulation), no clock and / or internal reference of voltage or current, similar to "system is not adequate for the voltage and frequency in the normal range".

- DC input side of the photovoltaic generator manageable with poles not connected to the ground, ie IT system.

- Compliance with general standards on EMC and RF emission limitation: according to EN 55014-1, EN 55011, EN 50082-1.

- Protections for disconnection from the network for values outside the threshold voltage and line frequency and overcurrent fault in accordance with the requirements of the local electrical distributor. Automatic reset of the protections for predisposition to automatic start.

- Degree of protection suitable to the location near the PV field (IP65).

The conversion system is composed of 1 inverter.

The power rating of the generator is given by:

$$
\mathrm{P}=\text { Pmodule } * \mathrm{~N}^{\circ} \text { modules }=285 \mathrm{~W} * 342=97470 \mathrm{~W}
$$

The total energy produced by the STC (radiation modules of $1000 \mathrm{~W} / \mathrm{m}^{2}$ at $25^{\circ} \mathrm{C}$ of temperature) is calculated as:

Where

$$
E=E n *(1-\text { Disp })=136428,1 \mathrm{kWh}
$$

Disp $=$ Power losses

The evaluation of the available solar resource was carried out according to standard Electro-Graphics, taking as reference the location that has historical data of solar radiation in the immediate vicinity of Elbasan.

The evaluation of the available solar resource was carried out according to standard Graphics, taking as reference the location that has historical data of solar radiation in the immediate vicinity of Elbasan.

\section{Conclusions}

A photovoltaic system uses solar panels, each of which contains a number of solar cells that generate electricity. PV installations can be mounted on the ground, mounted on the rooftop or mounted on the wall. The mountain can be fixed, or use a solar tracker to follow the sun through the sky. 
Solar PV has specific advantages as a source of energy: once installed, its operation generates no pollution and no greenhouse gas emissions, it shows a simple scale for energy needs and silicon has great availability in the Earth's crust.

PV systems have a greater disadvantage than power generation depends on direct sunlight, so about $10-25 \%$ is lost if no tracking system is used, as the cell will not directly face the sun at all times. Dust, clouds and other things in the atmosphere also reduce energy production (Oehler, 2007). Another key issue is the concentration of output in the hours corresponding to the main insulation, which usually do not match the peak demand in cycles of human activity. Unless the current social patterns of consumption and electrical networks fit mutually with this scenario, electricity should still be retained for later use or consist of other sources of energy, typically hydrocarbons (O'Connor, 2016).

Photovoltaic systems have long been used in specialized applications and independent PV and network systems have been in use since the 1990s (Holt, 2017). They were produced massively in 2000, when German environmentalists and the Eurosolar organization received government funding for a ten-thousand-roof program.

Advances in technology and increased production scale have reduced costs, increased reliability and increased photovoltaic efficiency. Net measurement and financial incentives, such as preferential electricity tariffs; have supported solar PV installations in many countries. More than 100 countries now use solar PV (Brooks et al., 2018).

Nowadays the renewable energy and its corresponding technologies are expanding in their usage. The limitations of this study consist in taking in consideration the economic benefits of using the solar plants. The economic approach is very important in front of the client, despite the technical aspect (Wulfinghoff, 2000). Thus, in this context the study should be considered limited in the aspect.

\section{References}

1. Brooks, B., White, S. (2018). Photovoltaic systems and the National electric code, London Routledge.

2. Chiras, D. (2011), The Homeowner's Guide to Renewable Energy: Achieving Energy Independence Through Solar, Wind, Biomass, and Hydropower, Philadelphia, PA, New Society Publishers.

3. Dunlop, J. P. (2012), Photovoltaic systems, Orland Park, IL. American Technical Publishers.

4. Holt, M. (2017), Understanding NEC requirements for solar photovoltaic systems, Leesburg, FL, Mike Holt Enterprises.

5. Isabella, O., Smets, A., Jäger, K., Zeman, M., van Swaaij, R., (2016), Solar Energy: The physics and engineering of photovoltaic conversion, technologies and systems, Cambridge, England, UIT Cambridge Limited.

6. Lebrac, V. (2017), "What is solar energy and how do solar panels work?", available at https://news.energysage.com/solar-panels-work/ (21 April 2018)

7. O'Connor, J. P. (2016), Off grid solar: A handbook for photovoltaic with lead-acid or lithium-ion batteries, San Francisco, CA, Createspace Independent Publishing Platform.

8. Oehler, M. (2007), The Earth-sheltered Solar Greenhouse Book: How to Build an Energyfree Year-round Greenhouse, Bonners Ferry, ID, Mole Pub Publishing Company.

9. Perlin, J. (2013), Let it shine: The 6,000-year story of solar energy, Novato, CA New World Library.

10. Provey, J., Barber, E. M. (2011), Convert your home to solar energy, Connecticut, Taunton Press. 
11. Prowse, W. E. (2017), Mobile Solar Power Made Easy!: Mobile 12 volt off grid solar system design and installation. RV's, Vans, Cars and boats! Do-it-yourself step by step instructions, United States, Prowse Publications.

12. Wulfinghoff, D. (2000), Energy Efficiency Manual: For Everyone Who Uses Energy, Pays for Utilities, Designs and Builds, Is Interested in Energy and Environmental Preservation, Energy Institute Press.

\section{About the authors}

Virtyt Lesha is electronics engineer, graduated at Polytechnic University of Tirana in "Master of Science in Elelctronics Engineering". He is specialized in digital signal processing and automatic control. Actually, he works at "Kurum International Sh.a." rolling mill plant in Albania in the position of automation engineer. Part of his experience is the scientific research for more than 5 years, which consists in publishing 3 monographs in Germany and more about 30 scientific papers in different international scientific conferences and journals. In this context, moreover he is member of different journals as scientific/editorial boards. The author can be contacted at virtyt.lesha@gmail.com. 